\title{
LA FOTOGRAFÍA ANTROPOLÓGICA EN LOS ANDES COMO TECNOLOGÍA DEL CONOCER: DESPLAZAMIENTOS Y EMPLAZAMIENTOS
}

\author{
ANTHROPOLOGICAL PHOTOGRAPHY IN THE ANDES AS KNOWLEDGE \\ PRODUCTION: DISPLACEMENT AND EMPLACEMENT
}

\author{
Mercedes Prieto ${ }^{1}$
}

\begin{abstract}
Este artículo explora los inicios de la Antropología visual y sus vínculos con los Andes; y, al mismo tiempo, subraya la reproductibilidad de la fotografía, característica que posibilita nuevos emplazamientos en lo que denomino álbumes comunitarios móviles. La Antropología visual propone a John Collier Jr. como uno de sus fundadores. Su contribución al establecimiento de este campo se sostiene en trabajos visuales realizados en distintos lugares de las Américas y Europa y en obras colaborativas con antropólogos y fotógrafos locales. El artículo documenta, a través de fuentes publicadas, su experiencia en los Andes y sugiere que esta novel área se constituye de cara a las disputas sobre la modernidad hacia mediados del siglo XX. Este escenario incluyó la expansión geográfica y temática de la Antropología norteamericana, así como las necesidades de un nuevo orden imperial que requería conocer, registrar e interpretar las transformaciones de distintos grupos humanos del mundo, en especial obreros y nativos. Los trabajos de Collier Jr. en los Andes contribuyeron a elaborar varios conceptos asociados a la visualidad: narrativas fotográficas, energía cultural y entrevista con fotografías, todos ellos dispuestos para comprender el cambio social en contextos interculturales de mayoría indígena. Hacia la década de 1940, la fotografía antropológica se mantiene como un modo de conocer el mundo de los pueblos nativos; pero ya no con el deseo eugenésico y de clasificación racial o de exotización, sino para dar cuenta del dinamismo de la indigenidad. Este dinamismo adquiere un nuevo ribete al constatar en el campo, a través de observación y entrevistas, que la fotografía antropológica de autor de mediados del siglo XX ha sido apropiada por la población de Otavalo (Ecuador) para conformar un álbum comunitario móvil, que otorga nuevos sentidos a las mismas imágenes. La materialidad de la fotografía y su apelación a los afectos propician estos desplazamientos y nuevos emplazamientos que conectan al público con ancestros otavaleños.

Palabras claves: historia de la antropología visual, fotografía, conceptos visuales, emplazamiento, afectos, álbum comunitario móvil, los Andes.
\end{abstract}

This article explores the beginnings of Visual Anthropology and its links to the Andean region. Additionally, it highlights the reproducibility of photography, a feature that allows for changes of location of past shoots in what I call mobile communal albums. The history of Visual Anthropology considers John Collier Jr. to be one of its founders. His contribution to this field is based on visual works carried out in several locations in the Americas and Europe and on collaborative works with local anthropologists and photographers. Through published sources, this article documents Collier's experience in the Andes, and suggests that this novel visual field was established in the context of disputes about modernity during the mid-twentieth century. This scenario included the geographical and thematic expansion of North American Anthropology, as well as the requirements of a new imperial order that demanded knowledge, registration, and interpretation of change among a diversity of human groups, particularly workers and native peoples. Collier Jr's work in the Andes contributed to the formulation of concepts associated with visuality, including photographic narrative, cultural energy, and photographic interview, all of which were used to understand social change in intercultural settings with a predominant indigenous population. Although towards the 1940s anthropological photography remained a technology to access indigenous worlds, rather than looking for eugenic and racial categorizations or for exoticization, it became a resource to understand the dynamism of indigeneity. This dynamism acquires a new layer when, through field observations and interviews, it can be noted that author photographs of the 1940s have been appropriated by residents of Otavalo (Ecuador) to compile a mobile communal album that assigns new meanings to old images. The materiality and affective appeal of photography allows such displacements to connect a contemporary public to Otavalo ancestry.

Key words: Visual anthropology history, photography, visual categories, placing, affects, mobile communal album, Andes.

La antropología visual reconoce a John Collier Jr. como uno de sus iniciadores (Biella 2002; Pink 2007; Scherrer 1992), con especial referencia a su contribución a una Antropología visual aplicada.
Collier Jr., un fotógrafo y antropólogo aficionado norteamericano, desarrolló sus propuestas visuales en varios escenarios: los Andes (Otavalo en Ecuador y Vicos en Perú), las cercanías de Bristol, Inglaterra,

1 Facultad Latinoamericana de Ciencias Sociales, FLACSO, Quito, Ecuador. mprieto@ flacso.edu.ec

Recibido: septiembre 2019. Aceptado: septiembre 2020.

http://dx.doi.org/10.4067/S0717-73562021005000601. Publicado en línea: 10-junio-2021. 
y América del Norte (Taos, Nuevo México y la bahía de San Francisco, entre otros lugares) ${ }^{1}$. En la década de 1940, realizó uno de sus primeros trabajos visuales fuera de los Estados Unidos en Otavalo, Ecuador, con la colaboración del antropólogo Aníbal Buitrón, estudiante en la Universidad de Chicago y originario de esta localidad. En este artículo exploro conceptos de la Antropología visual aplicada y algunos efectos locales de las imágenes, tomando como acceso central la pieza de fotografías y escritura, El valle del amanecer, que fuera divulgado, originalmente en 1949, por la Universidad de Chicago ${ }^{2}$, así como algunos fragmentos de su trabajo en Vicos, Perú, publicados parcialmente (Collier 1957; Collier 2003).

La historia de la Antropología visual ha recibido relativamente poca atención, pero la historia de la fotografía ha concitado una amplia atracción de parte de diversos estudiosos. De manera particular, resulta estimulante la compilación de Elizabeth Edwards sobre la trayectoria de la fotografía antropológica en el siglo XIX (1992) e inicios del XX (2012). Su aporte fundamental ha sido mostrar historiográficamente que este tipo de fotografía es un objeto fragmentado, descontextualizado y congelado del tiempo y el espacio (Edwards 1992), y por ello no puede considerarse una reproducción transparente de la "realidad"; al contrario, es un objeto construido $y$, como aseveran varios autores, tiene distintas inspiraciones e intereses (Wright 1992); lo que contemporáneamente ha dado paso a la idea de la fotografía como montaje (Didi-Huberman 2015). Hacia la década de 1990, para varios fotógrafos y estudiosos de la fotografía, el reponer los contextos, enhebrar los fragmentos y pensar el movimiento del tiempo y el espacio son desafíos relevantes de esta tecnología; son una forma de aventurarse a nuevas maneras de conocer y de hacer fotografía antropológica, un terreno en el cual Collier Jr. fue antecesor.

Asimismo, en esos tiempos se consagra la noción de que la fotografía conjuga al menos la mirada de tres agentes: el fotógrafo, el sujeto y el espectador (Sherrer 1992). Sin embargo, es posible ampliar la noción de espectador hacia la del investigador, hacia la de los sobrevivientes y familiares actuales de las personas fotografiadas y hacia el público debido a la materialidad, reproductibilidad y desplazamiento de la fotografía, según se muestra en este artículo. Y, como resultado de historiar la fotografía, Philipp Dubois (1994 [1986]) registra tres maneras de usarla y analizarla: como espejo de la realidad o de lo real, buscando una mimesis; como distorsión de lo real, toda vez que hay diversos códigos e intereses en el material fotográfico; y como huella de la realidad. La idea de huella reconoce al acto de fotografiar y a los desplazamientos de las imágenes como un complejo despliegue de sentidos. Esta última propuesta deja entrever que la fotografía y las imágenes son objetos que permiten ampliar y complejizar el conocimiento, en la medida en que en un mismo objeto se cruzan movimientos y agencias, lo que las hace un recurso conceptual y metodológico problemático, múltiple y en constante reinterpretación.

Se han realizado ingentes estudios sobre los variados usos de la fotografía antropológica: sobre las colecciones de vocación etnográfica y las tipologías raciales con referencia, por ejemplo, a los autores de las producciones, a los sentidos y a las políticas de las propias compilaciones. Otros estudios han tratado los archivos fotográficos, exhibiciones y demás formas de circulación de estos objetos (p.ej., en los Andes, Cánepa y Kunnels 2016; Reyero 2012; Troya 2012;). También se ha subrayado la política de la fotografía y la economía política de las imágenes (Poole 2000 [1997]). En general esta literatura ha quedado inscrita en la noción de que la fotografía es una representación interesada de la realidad, dejando de lado, en muchas ocasiones, cómo la fotografía abre el entendimiento de procesos históricos, de los múltiples caminos seguidos por las imágenes y de las posibilidades de agencia de los propios sujetos fotografiados; es decir, se ha escamoteado un discernimiento de la fotografía como una huella compleja de la historia, con su propia materialidad y capacidad para entrecruzar múltiples sentidos. Recientemente, sin embargo, estos mismos autores rescatan la agencia política de los sujetos fotografiados en el marco del trabajo etnográfico realizado por antropólogos (Poole y Zamorano 2012; Zamorano 2009).

Philipp Dubois (1994 [1986]) y Robert M. Levine (1989) han sido pioneros en proponer las maneras en que la fotografía abre la comprensión de los procesos históricos al llamar la atención sobre pequeños fragmentos de las imágenes que recuperan historias escondidas de la vida cotidiana. Al mismo tiempo, esta literatura expone la necesidad de contextualizar la búsqueda de los sentidos de las imágenes fotográficas. Lo que no exploran estos estudios son los lugares de producción, los conceptos desarrollados a partir de las imágenes y los desplazamientos de las fotografías -los objetivos de este trabajo-. Mediante la exploración del trabajo de John Collier Jr. junto a Aníbal Buitrón y Abraham Guillén, este ensayo 
recupera las relaciones y contextos de las imágenes y de escritos acompañantes con el conocimiento, para así provocar una Antropología visual aplicada, en el marco de la posguerra y del creciente protagonismo global de Estados Unidos que conecta a las Américas y Europa. De igual manera, sigue a las fotografías hoy en día en algunas instituciones locales y comunidades indígenas comprometidas en las imágenes. El propósito es localizar la fotografía (Edwards 2012:226) y reflexionarla como una tecnología del conocer, como narrativa y evocación de los cambios de los sujetos y sus contextos -justamente uno de los deseos de Collier Jr.- así como sus emplazamientos contemporáneos que la vinculan sensorial y afectivamente (Edwards 2012:228) a nuevos espectadores.

\section{La Antropología de la Posguerra en los Andes}

Durante la guerra, pero especialmente en la posguerra, Estados Unidos se mostró ávido de información cultural, de ensayar maneras de conocer a los pueblos y de promocionar la democracia global en el marco de la disputa por un nuevo orden imperial ${ }^{3}$. La antropología de esa nación, que había estado centrada fundamentalmente en asuntos de política disciplinaria interna, expande sus escenarios de producción del conocimiento a diversos subcampos y a múltiples lugares del mundo, al tiempo que refuerza la noción de cambio cultural como el eje de su curiosidad disciplinaria (Kehoe y Doughty 2012). La idea de cambio estuvo inspirada, inicialmente, por las teorías antropológicas funcionalistas y, posteriormente, por las teorías de la modernización (Prieto y Páez 2017:1921) bajo preceptos positivistas. En ambas vertientes, se considera que el cambio es inexorable y que se debe mantener el equilibrio entre las partes o entre las diversas estructuras que conforman la cultura y la sociedad para no producir desorden. A su vez, la cultura es vista como un todo armónico, que configura particulares y cambiantes patrones y rasgos encarnados en los individuos, una suerte de ethos cultural.

Una de las maneras de entender el cambio es a través de lo que se llamó "aculturación" tanto a nivel estructural como de la personalidad de los individuos (Bee 1974:112). Este acceso al cambio cultural, presente en la antropología norteamericana desde inicios de la década de 1930, se conecta con la necesidad de la reconstrucción histórica de los patrones culturales, un esfuerzo considerado riesgoso, si bien plausible, por la falta de documentación y por el dilema de localizar la zona cero desde la cual se observan los cambios; todo ello incita al desarrollo de metodologías comparativas globales para el estudio de la aculturación (The Social Science 1954:992-993). Este interés por el cambio y el desafío metodológico convergen, a su vez, en una agenda de trabajo que debe no solo documentar e informar las transformaciones, sino intervenir estas transformaciones, con lo cual se vigoriza un campo aplicado para la Antropología (Doughty 2010) .

El trabajo fotográfico de John Collier Jr. y los escritos de Aníbal Buitrón, en Ecuador, y de Collier Jr. con Abraham Guillén, en Perú, dan cuenta de los procesos de expansión geográfica de la disciplina antropológica, de la inquietud y el registro del cambio cultural, así como del desarrollo de un emergente enfoque visual y aplicado. La obra de Collier Jr. ha sido tildada como un producto de su tiempo que contiene "a strong humanist bias and expresses a modernist faith in positive knowledge and an empirical world" (Biella 2002:50). En su obra, una sensibilidad humanista y artística se unen en la búsqueda de evidencia empírica y de procedimientos positivistas de medición. Pero además de ello, se trata de composiciones de transición en una fotografía antropológica que intenta desligarse de la imagen con fines eugenésicos, de clasificación racial o de exotización de la alteridad y avanzar hacia un uso conceptual y metodológico de las imágenes, que permita expandir los conocimientos culturales, capturar la aculturación, producir narrativas fotográficas e intervenir la "realidad".

La Antropología de la guerra y posguerra hace parte también de la política de los "encuentros cercanos" y disputados del imperio norteamericano (Gilbert et al. 1998). Estas políticas comprenden una serie de prácticas cotidianas en las ciudades, intercambios entre intelectuales, apoyos a las universidades y emergentes instituciones estatales y el fortalecimiento de los "estudios de áreas", que para el caso en análisis se refiere a los estudios andinos ${ }^{6}$. En los Andes convergen antropólogos de Europa, Estados Unidos y de las naciones andinas, atraídos por la gran proporción de población considerada indígena y por la grandeza de lo que había sido el Imperio Inca. En este ambiente, por ejemplo, se establecen en las universidades peruanas los estudios de Antropología en los cuales enseñan profesores de diversos orígenes ${ }^{7}$. El mismo Collier Jr. aterriza hacia 1950 en Vicos, Callejón de Huaylas (Perú), donde trabaja con el equipo de la Universidad de Cornell, con su esposa y con el fotógrafo local, 
Abraham Guillén. En Quito, en la década de 1940, se encuentran antropólogos y fotógrafos como la norteamericana Elsie Clews Parsons, discípula de Franz Boas, quien trabaja con el fotógrafo europeo Bodo Wuth para ilustrar su etnografía Peguche (Parsons 1945). Como ya indicamos, Collier Jr. coincide con Aníbal Buitrón y con el fotógrafo de grupos indígenas, André Roosevelt, nacido en Paris, quien expone en Quito su obra junto a la estudiosa y coleccionista de artes populares, Olga Fisch ${ }^{8}$. Varios de estos fotógrafos parecen llegar a los Andes auspiciados por empresas norteamericanas y como efecto de la persecución hacia los judíos en Europa ${ }^{9}$. A su vez, Pío Jaramillo Alvarado, el más destacado indigenista ecuatoriano, muy relacionado con los diversos antropólogos y fotógrafos antes referidos, viaja a conocer la administración indígena de los Estados Unidos, invitado por John Collier padre.

De manera que no solo se expanden las localizaciones del hacer antropológico, sino que se establece una comunidad de antropólogos compleja y diversa, articulada a la manera de una red que tiene varios nodos desde los cuales se atienden preocupaciones conceptuales y metodológicas e intervenciones para entender y canalizar el cambio entre los pueblos indígenas ${ }^{10}$. Uno de estos nodos es el Instituto Indigenista Interamericano (III), con sede en Pátzcuaro, México. Según Thaddeus Blanchette (2010), la antropología aplicada se sistematiza en la Oficina de Asuntos Indígenas de los Estados Unidos, la cual estuvo, a su vez, vinculada al III, concebido por John Collier padre como un nodo de distribución de prácticas antropológicas sobre los indios de las Américas ${ }^{11}$. Esta sistematización, sin embargo, fue controversial y las propuestas para el trato a los pueblos indígenas dejaron espacios para la innovación local (Rosenblatt 2018). Otros nodos fueron la Organización Internacional del Trabajo (OIT), con sede en Ginebra y Lima, y la Organización de las Naciones Unidas para la Educación, la Ciencia y la Cultura (UNESCO), con su sede en París. Aníbal Buitrón y Alfred Métraux se vinculan a este último núcleo y desde allí hacen política indigenista, acopian conocimientos y diseñan intervenciones de mejoramiento de la educación indígena. La OIT, por su parte, sistematiza la información de las poblaciones indígenas en el mundo preocupada por su condición de segregación y propone su protección social (Prieto 2016). Asimismo, las universidades se transforman en lugares de encuentros entre diversos estudiosos de las poblaciones indígenas -como lo atestigua el proyecto Vicos (Bolton et al. 2010)- o de disputas ideológicas relativas a los modelos de la modernidad deseada (Purcell y Casals 2015).

En estos distintos nodos o pequeños centros de conocimiento ${ }^{12}$, pero también en los ambientes intelectuales citadinos cotidianos, en los cuales se inserta el trabajo de Collier Jr., se refuerza un interés por las poblaciones indígenas del presente y de su pasado. Se rescatan tradiciones, lenguas y artesanías a la vez que se estudian los cambios culturales. Se visita el "campo", se implementan intervenciones de integración y desarrollo y se buscan explicaciones a la decadencia de la población indígena, al tiempo que se consideran las condiciones favorables al cambio social y cultural. Hay un sentido de urgencia y un renacer indigenista que busca -en cronistas imperiales del pasado, en la arqueología y en sus objetos materiales y en otras fuentes históricas y orales- las posibilidades para que lo indios andinos retomen la senda del progreso demostrada en la organización del Incanato (Métraux 1962, 1969).

\section{Una Mirada en Movimiento: Narrativas Sociales Fotográficas}

El valle del amanecer es una muestra del vibrante ambiente de la Antropología en los Andes. Es una obra que contiene cerca de 180 fotografías acompañadas de texto escrito, organizado en cuatro secciones referidas al Valle de Otavalo y a los indios, su vida cotidiana y comunitaria y al amanecer del valle. El escrito se abre señalando la centralidad de la población india para el futuro de las naciones andinas y sugiere que la gran mayoría de sus habitantes es indígena. El argumento central de la obra es que la condición de sumisión, pobreza y decaimiento de los indios Otavalo en la época del registro fotográfico es una derivación del coloniaje español, el cual se mantuvo durante la época republicana con base en la ignorancia, el prejuicio y la decadencia social. Este valle, sin embargo, registra un milagro de renacimiento cultural, una narrativa articulada a lo que algunos autores contemporáneos llaman el "mito otavaleño" (Windmeijer 2016 [2001]:21) ${ }^{13}$. Estos indios, según Collier Jr. y Buitrón (1971 [1949]), promovieron por su propia iniciativa una dinámica que fisura los lazos de dependencia y pobreza a través del comercio, de la industria textil y de la compra de tierras -actividades todas que los configuran como ciudadanos independientes-. Los autores creen que se trata de una historia única que debe ser compartida globalmente, de una experiencia 
que podría ser replicada en cualquier lugar ya que su motor ha sido el mercado, concebido como institución universal; es, en suma, un relato de los efectos positivos del mercado en la vida económica y ciudadana de los pueblos indígenas.

Al final del libro aparecen los agradecimientos y se hace una corta mención a cómo fue su elaboración. Se reconoce a dos grupos familiares como colaboradores, aunque no se identifican individualmente a los participantes. En esta sección se subraya, justamente, el carácter colaborativo e interpretativo del libro, así como el esfuerzo por combinar el método científico con la sensibilidad de un artista fotógrafo. Uno de los propósitos explícitos de la pieza es desplegar una narrativa social de las imágenes y con ello romper con la idea de la fotografía como un recurso de interpretación congelado en el tiempo y en el espacio. El texto debía comunicar el cambio positivo de los indios, explicitar los motores de este cambio cultural o aculturación y, por esta vía, universalizar el lugar de enunciación. Efectivamente, nos dicen que se ha intentado "to fit the sequence of the photographs and to interpret the ethnological material as a social narrative" (Collier y Buitrón 1971 [1949]:199). Se reitera de esta forma el intento de escapar a las narrativas e imágenes antropológicas como objetos fragmentados y aislados mediante su propuesta de relato fotográfico, de imágenes encadenadas con sentidos. Ello requiere de, al menos, dos estrategias retóricas visuales que dan cuenta de los procesos de aculturación en marcha: el establecimiento de algunos contextos y el registro del movimiento.

Los contextos son comprendidos desde la ecología del lugar: el mercado y los vínculos estatales con la nación. En esos momentos la ecología era concebida como el espacio de contactos interculturales (The Social Science 1954:979). La fotografía de apertura y la retórica siguiente proponen, justamente, la idea de que la ecología permite enfrentar el congelamiento de fragmentos, ya que conecta diferentes lugares y así establece un escenario complejo de múltiples relaciones. La primera fotografía del libro es una imagen de $180^{\circ}$ en la cual se coloca a Otavalo como lugar central de un valle recortado por montañas y un lago. Este amplio escenario se mueve en torno al mercado de Otavalo (Figura 1), lugar de intercambio de los productos indígenas e industriales.

En la contextualización ecológica, el lugar central de Otavalo se refuerza con el establecimiento de relaciones con agentes estatales masculinos localizados

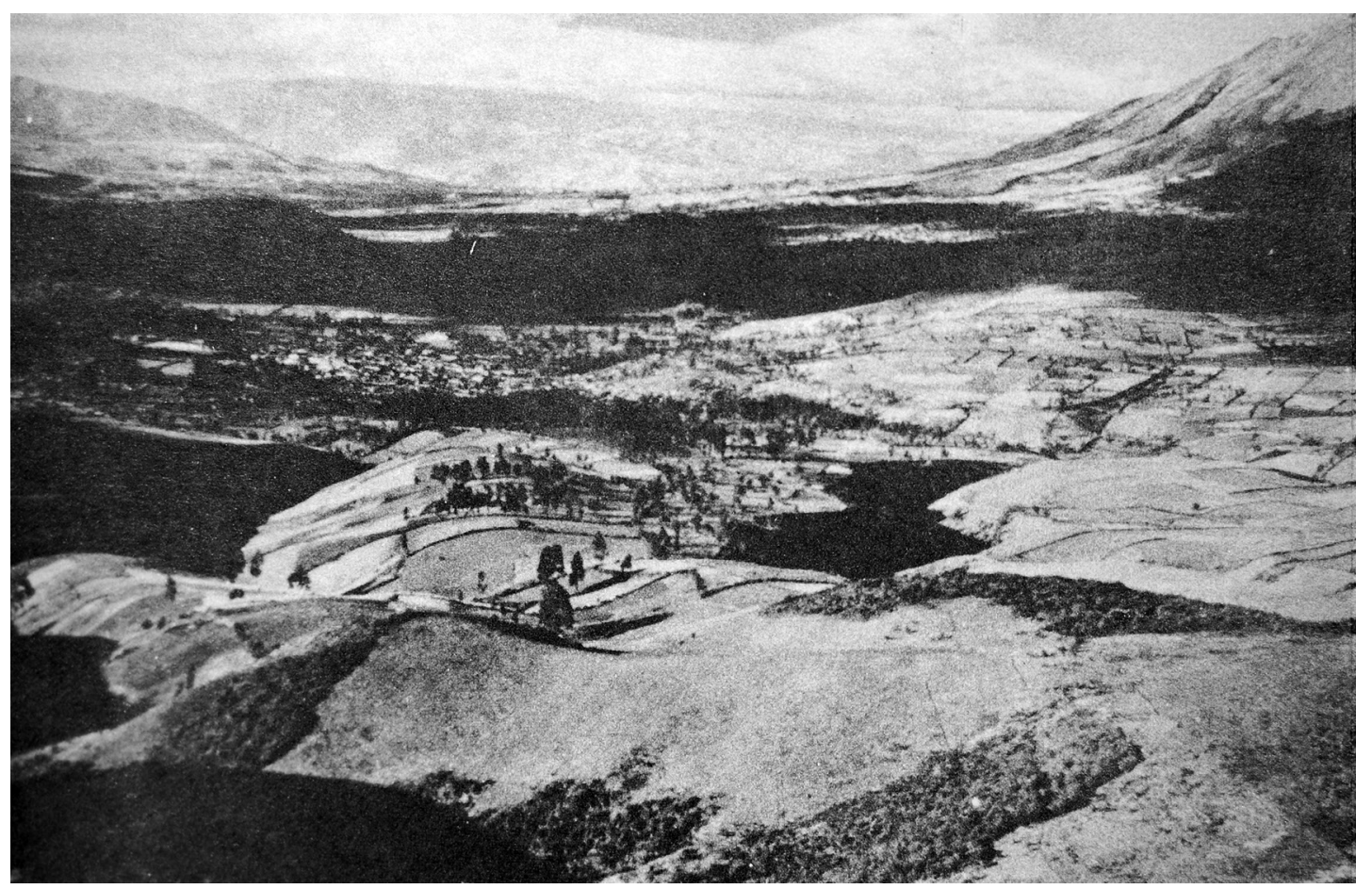

Figura 1. Contexto ecológico (fragmento). Fuente: Buitrón y Collier 1971[1949]:2.

Ecological context (fragment). Source: Buitrón and Collier 1971 [1949]:2. 
en este mismo poblado: el comisario político, el policía municipal y el maestro, quienes aparecen como intermediarios benevolentes con la nación. En la Figura 2, por ejemplo, aparece el comisario político, junto a un policía, dialogando con un grupo de indígenas sentados frente a su escritorio y haciendo contacto visual con uno de ellos. No parece haber sido una práctica habitual que los indígenas se sentaran en las oficinas públicas; solían o estar parados o bien, sentados en el piso y en muchas ocasiones el contacto visual era catalogado como un atrevimiento de parte de los indígenas. Un gran ausente del relato fotográfico es la figura del terrateniente, aunque hay imágenes de casas de haciendas. Son como fantasmas, aunque agentes relevantes de la explicación del decaimiento indígena, cuyos lazos con los indígenas se han debilitado y así se abre una trayectoria hacia la autonomía. De esta manera, los mercados, como lugar de transacciones, y la burocracia estatal, como agentes mediadores, son los hilos contextuales que dan un sentido de autonomía ciudadana a los indios de Otavalo.

Junto a los escenarios contextuales, la retórica de las imágenes establece una comprensión de los diversos movimientos comprometidos en la vida indígena: por ejemplo, primero, los desplazamientos de los sujetos a través de caminos y chaquiñanes para acceder a los mercados y ferias, a lugares de trabajo y sitios de celebración de diversos acontecimientos; y, segundo, la circulación de personas provocada por la cooperación comunitaria y las negociaciones en los mercados. La Figura 3 muestra el movimiento en el mercado de Otavalo. El movimiento aparece, así, vinculado a la sociabilidad de dimensiones extra-hogar entre una población social y culturalmente diversa -lo que en esta época se llamaba interculturalidad (The Social Science 1954)-. Las imágenes de los cuerpos en marcha introducen, metafóricamente, un sentido de transformaciones y cambios: cambios de estados de ánimo, encuentros con otros, accesos a deseos imaginados, libertad de movimientos, entre otros. Son cuerpos en marcha encuadrados desde las espaldas, donde se enfatiza el horizonte por venir. En suma, estas imágenes parecen ser parte de una retórica de las maneras en que los indios de Otavalo elaboraban su propia autonomía, un requisito de la democracia.

Hemos adelantado ya que uno de los aspectos centrales del movimiento es el recorrido hacia las ferias

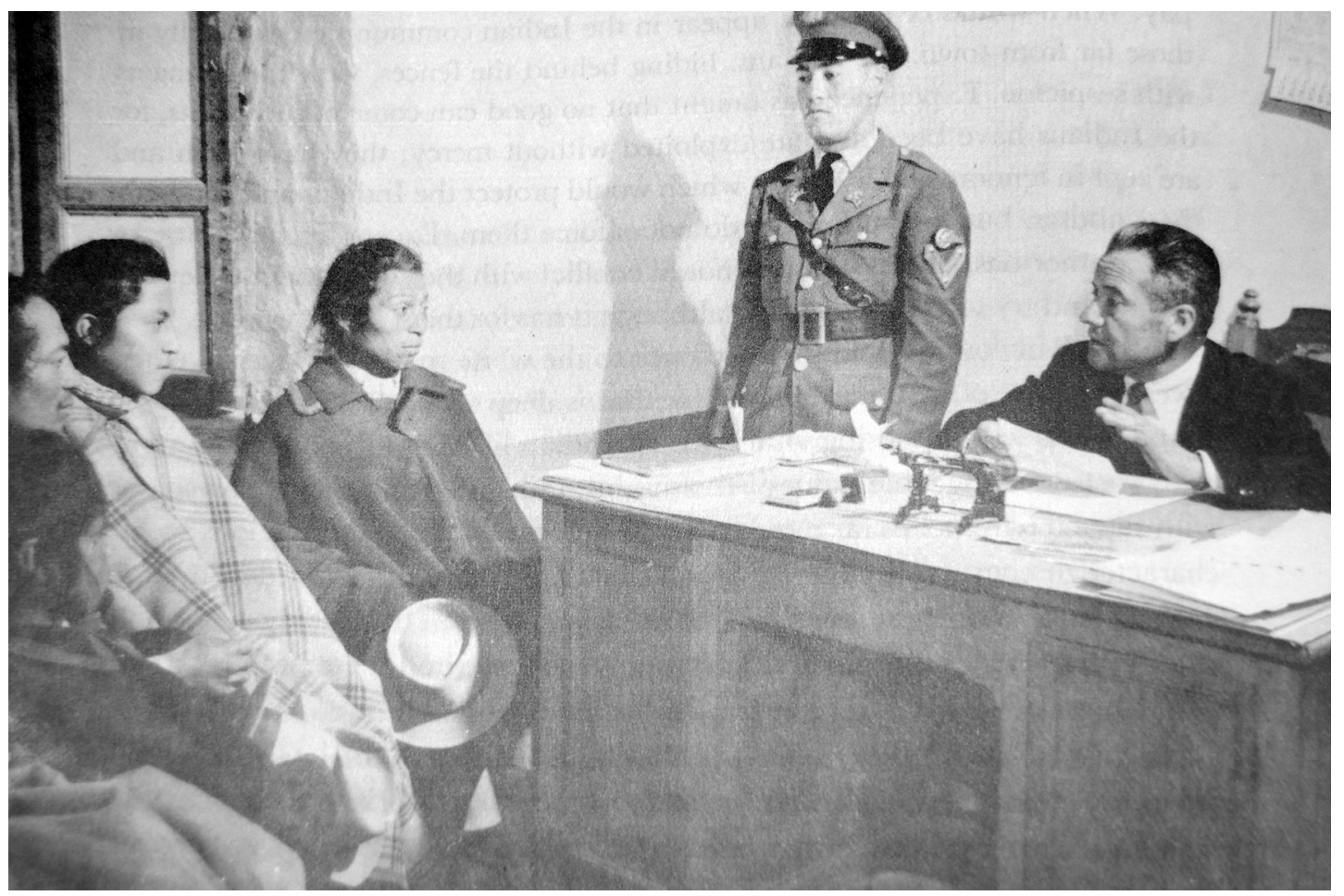

Figura 2. Contexto político (frente a las autoridades locales). Fuente: Buitrón y Collier 1971 [1949]:92.

Political context (facing local authorities). Source: Buitrón and Collier 1971 [1949]:92. 


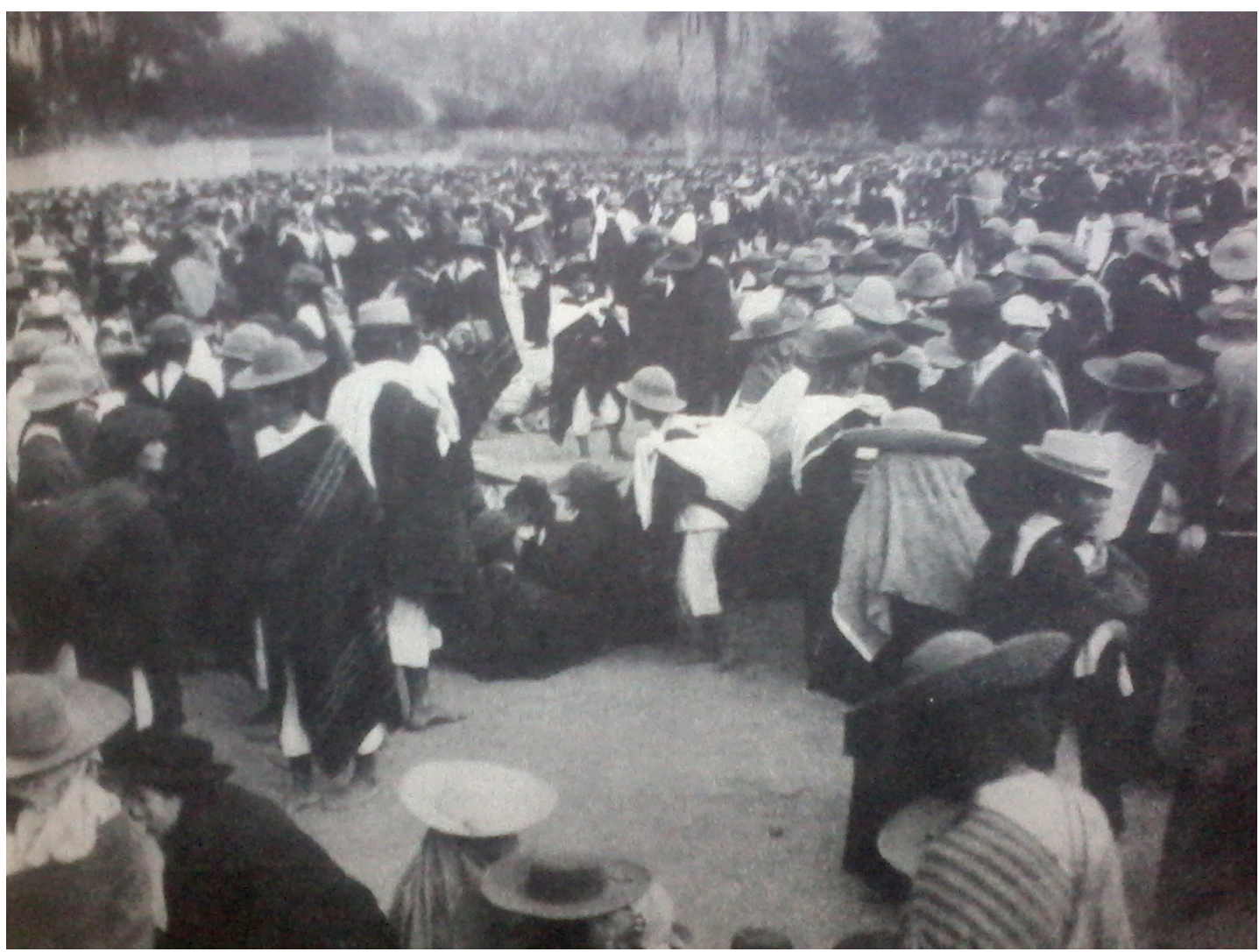

Figura 3. Movimiento semanal en el mercado al aire libre. Fuente: Buitrón y Collier 1971 [1949]:27

Activity in the weekly open market. Source: Buitrón and Collier 1971 [1949]:27.

realizadas en Otavalo. El texto de la obra propone que los mercados son de origen precolombino y que, desde esa época, permiten establecer conexiones entre distintas geografías. Con el paso del tiempo, estas conexiones se han ampliado $\mathrm{y}$, al momento de producción de las imágenes, se sabe que los productos textiles de los indios de Otavalo recorren Ecuador y llegan hasta Bogotá y Caracas. Asimismo, se insinúa que el mercado es un elemento estructurante de la vida cotidiana de los indios; todo el trabajo y actividades de la semana se organizan para desembocar los sábados en Otavalo. Las ferias son espacios de sociabilidad y de encuentro de personas de distintos orígenes: mestizos, afros y blancos, con quienes se negocia y se establecen acuerdos de diversa naturaleza. De cierta manera, el mercado se configura como el escenario de los cambios culturales y de las sociabilidades, aunque al mismo tiempo da cuenta de prácticas rutinarias y de larga duración. Por su parte, los nexos con la burocracia estatal ${ }^{14}$, a quien se le reconoce y respeta y de quien los indios, a juicio de los autores, reciben un buen trato, dan cuenta del establecimiento de formas de comportamiento ciudadano. La participación indígena en litigios legales y en la escuela, y su vigilancia por parte de la policía, según la retórica de las imágenes, serían parte de la vida indígena en los poblados.

A contrapelo de los sentidos de movimiento antes descritos, y con el propósito de resaltarlos, la obra presenta una serie de imágenes que dan espacio a prácticas culturales, también universales, en la quietud de los entornos familiares y caseros. Estos son momentos de sociabilidad familiar en los cuales se cocina, se alimenta y cría a la prole y también se trabaja. En la Figura 4, madre e hija intercambian sonrisas un tanto irónicas mientras la mamá sirve la sopa en un plato; y en la Figura 5 un joven teje concentradamente una faja en un telar de mano. Son escenas que remiten al quehacer de familias -aparentemente- nucleares y menos expuestas a cambios; son espacios de reproducción de la indigenidad, donde se fermenta un sentido positivo de esta identidad, algo así como la energía para el cambio. 


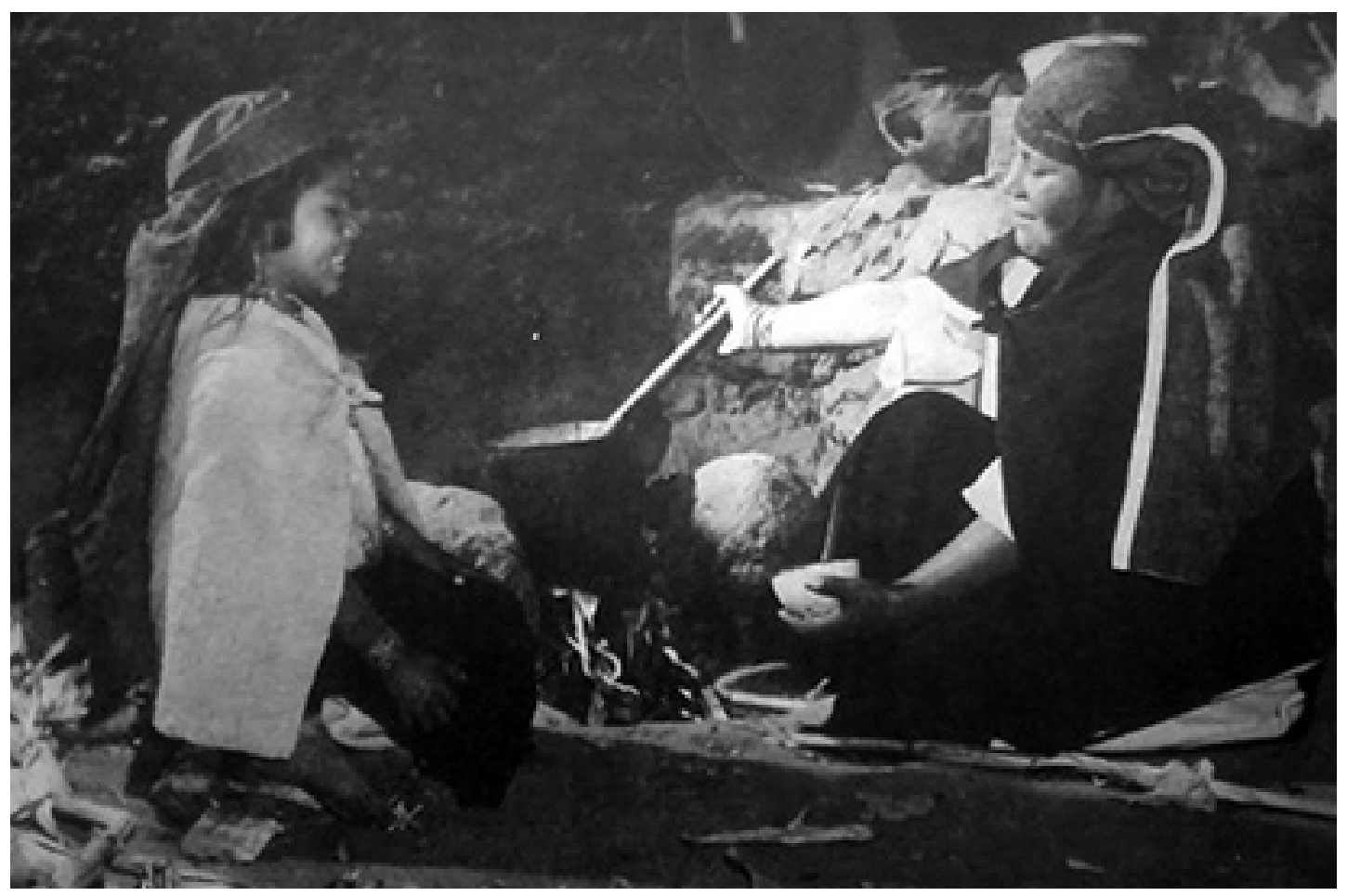

Figura 4. Reproducción de la indigenidad. Fuente: Buitrón y Collier 1971 [1949]:83.

Reproduction of indigeneity. Source: Buitrón and Collier 1971 [1949]:83.

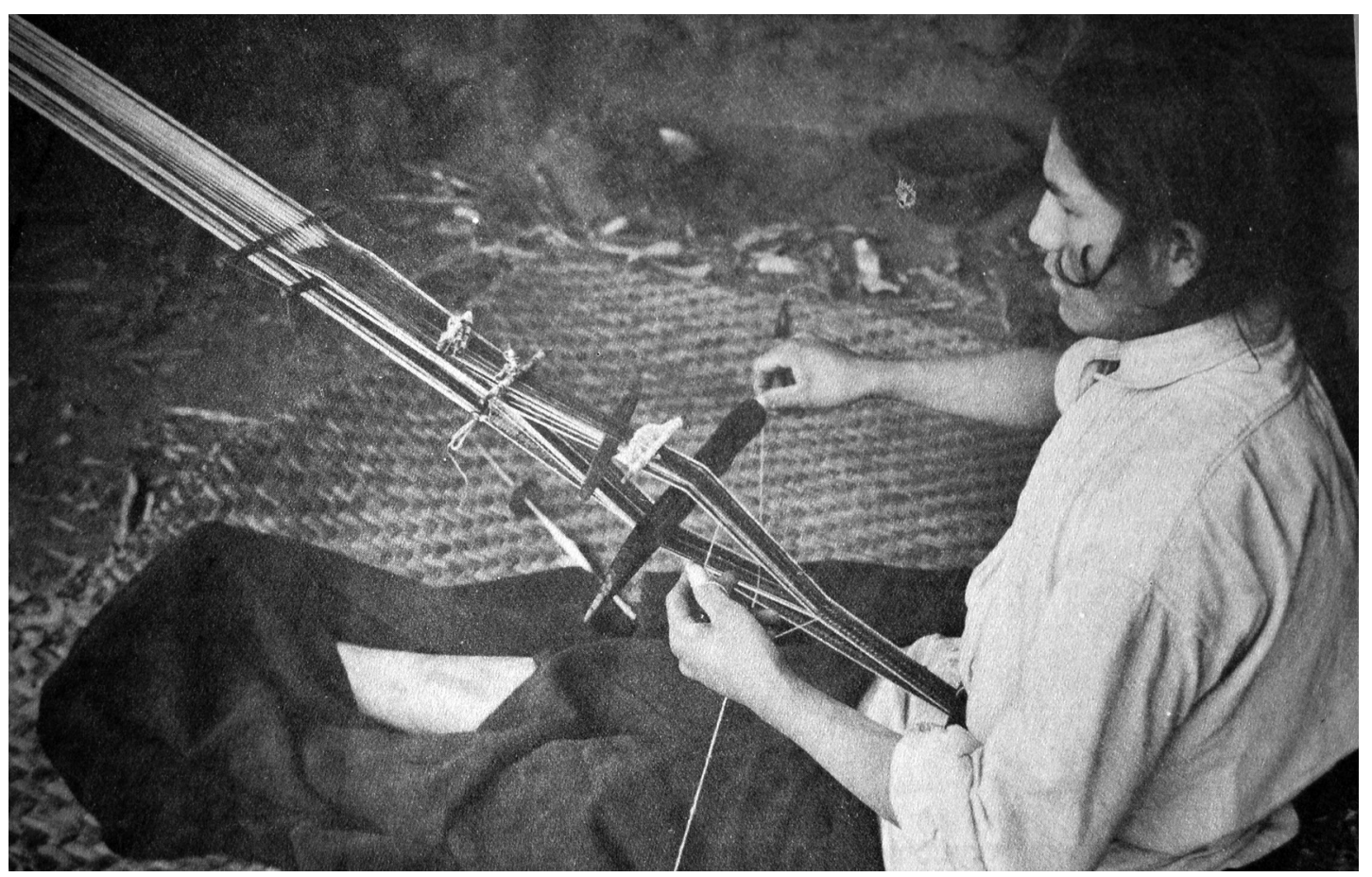

Figura 5. El trabajo. Fuente: Buitrón y Collier 1971[1949]:71.

Active at work. Source: Buitrón and Collier 1971 [1949]:71. 


\section{Capturando la Energía para el Cambio}

Una tercera estrategia retórica de las imágenes es capturar la energía positiva para el cambio, una suerte de "energía cultural" o "vitalidad cultural". Usando concepciones provenientes de los estudios de la psicología sobre las proyecciones de vida de los sujetos, muy frecuentes en la antropología norteamericana de la posguerra (Kehoe y Daughty 2012), en un acápite titulado "Horizontes" (Collier y Buitrón 1971 [1949]:194-196), se describe a los indios como saludables, fuertes, inteligentes, despiertos y sonreídos, entre otras características positivas, que contrastan con la apatía y aislamiento de los indios en la ciudad y en las haciendas. Se proyectan en estos escenarios de confinamiento como seres trasplantados, ya que su raíz y lugar es junto a la tierra. Han adquirido, a través del ensayo y el error, objetos modernos y se han ajustado a las ventajas de la vida moderna -expresión del proceso de aculturación- sin destruir su espíritu indígena. Al mismo tiempo que se resaltan los elementos de la energía cultural positiva para el cambio y los procesos de aculturación, se contrasta la vida indígena en el valle con aquella de la población blanco-mestiza de los poblados -la cual se retrata sin proyección de futuro-. Los blanco-mestizos no tienen la energía y fe de los indios, depositada en la tierra, su tierra, a la cual se mantienen profundamente unidos con un sentido que trasciende la individualidad y con la fortaleza que les provee la naturaleza. En otras palabras, la energía cultural para el cambio está arraigada en la tierra de origen ${ }^{15}$. Estas raíces provocan y proyectan las dimensiones culturales positivas para el cambio y garantizan procesos de transformación ordenados y que aseguran el equilibrio de las distintas dimensiones culturales. Así, el vínculo con la tierra sería lo que algunos antropólogos de la época llamaban la dimensión integradora de la cultura. El desafío, por lo tanto, es garantizar y reforzar la permanencia del conglomerado otavaleño en su tierra originaria y evitar las migraciones. El milagro social vivido por los indios Otavalo se produce y se proyecta desde estos lugares geográficos y culturales.

A lo largo de la obra aparecen una variedad de imágenes de los lugares culturales y de la gente. Se captura la energía positiva a través de imágenes del paisaje, lugares rituales, prácticas agropecuarias, trabajo laborioso en la tierra y en los telares, cotidianidad en los hogares, entre otras prácticas. De manera especial, los rasgos positivos de la personalidad india se despliegan mediante retratos de adultos orgullosamente ataviados con impecables trajes, pero sobre todo a través de niños que trabajan, hacen música, van a la escuela y miran orgullosamente a la cámara (Figura 6).

Poco sabemos sobre las dinámicas provocadas al capturar las imágenes de la energía, de los contextos y de los movimientos; esto es, aquellas dinámicas desatadas por la cámara de fotos y por las mismas fotografías en las vidas de las personas involucradas y en los procesos de conocer de parte de las personas retratadas. Estos son aspectos silenciados en el libro, así como la identificación de las personas que aparecen en las fotografías. Se adelantó ya que en los agradecimientos de la obra se mencionan a Manuel M. Cáceres y su familia, de Ilumán, y a José Maldonado y sus vecinos, de La Compañía. Ellos son protagonistas y colaboradores del texto. Varios años después de la experiencia en Otavalo, John Collier Jr., junto a su hijo el antropólogo Malcolm Collier, al formalizar el campo de la Antropología visual y sistematizar su experiencia en diversos lugares del mundo (Collier y Collier 1986 [1967]:71-73), comentan que, en la zona de Otavalo, la cámara estimuló a los fotografiados a narrar, explicar y

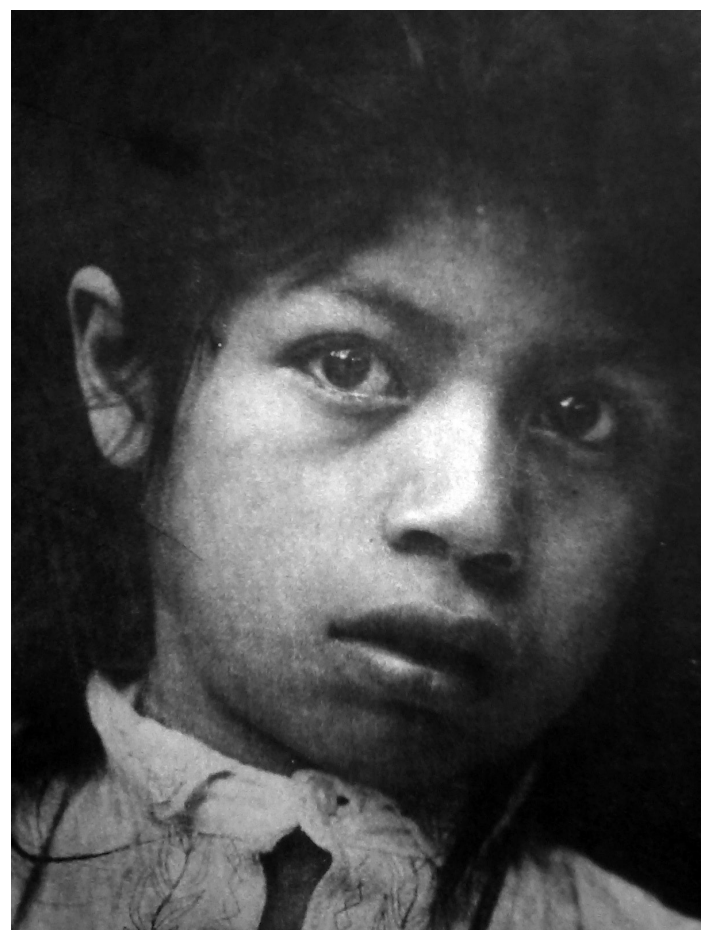

Figura 6. Energía cultural. Fuente: Buitrón y Collier 1971 [1949]:192.

Cultural energy. Source: Buitrón and Collier 1971 [1949]:192. 
precisar los detalles tecnológicos de los tejidos. Las fotos fueron una herramienta para compartir las reacciones sobre el trabajo textil -especialmente la fabricación de tweed-. Se relata que habían tenido dificultades de acceso para documentar la tecnología de los tejidos; los tejedores de la zona se mostraban poco cooperativos con el esfuerzo, especialmente por las creencias sobre los peligros de la fotografía -un potencial ladrón del espíritu de las personas- y los riesgos de ser explotados por un gringo ${ }^{16}$. En esa disyuntiva, los autores piden a un reconocido tejedor que les haga una pieza de tweed. Presumiblemente se trata de Manuel Cáceres, cuyo nombre es soslayado por los Collier. Acordaron el precio y se definió, como requisito del contrato, fotografiar el proceso completo de la confección, desde de la preparación de las lanas. El tejedor, después de meditar la oferta, accedió ya que, finalmente, la pieza de tweed sería usada por los compradores para confeccionar su propio vestuario. Se registró, bajo este acuerdo, la primera parte del proceso; luego imprimieron las fotos y con ellas regresaron donde el tejedor. Le entregaron las pruebas de las imágenes, frente a las cuales el artesano quedó sorprendido. Puso las fotos en el piso en secuencia, las observó y reclamó que no se había hecho un buen registro de su trabajo y que los espectadores lo verían como un mal tejedor. Pidió, entonces, repetir el proceso para que se muestre mejor cada uno de los pasos de la preparación y confección de la pieza, lo cual honraría su habilidad de tejedor. En este nuevo intento, él indicaría el momento de disparar la cámara ${ }^{17}$. Cuando volvieron por segunda vez con las nuevas fotos, el artesano se mostró satisfecho y pudieron continuar con la siguiente etapa del trabajo. La dinámica cooperativa abrió las puertas para otros registros de tejidos de la zona y permitió hacer un estudio más completo de la actividad textil. Esta experiencia y otras similares fueron las bases de lo que más tarde los Collier llamarían las "entrevistas con fotografías" (Collier y Collier 1986 [1967]):99138) y que hoy se conoce como "foto-elicitación". Se trata de entrevistas estimuladas por el feedback que las fotografías producen en los sujetos etnográficos; estos accesos, a su vez, enriquecen el concepto de narrativas sociales fotográficas.

\section{Vicos: Hacia una Metodología Visual del Cambio}

Una década más tarde, John Collier Jr. viajó hasta Vicos, en Perú, con el propósito de realizar una línea de base que permita, a futuro, documentar los presuntos cambios gatillados por una intervención auspiciada por las universidades de Cornell y de San Marcos. Se trató de un proyecto de introducción de nuevas tecnologías agropecuarias y de servicios sociales para mejorar la vida de trabajadores de una ex hacienda y sus familias (Bolton et al. 2010). En este marco, el interés de Collier Jr. fue, justamente, ensayar el uso de la fotografía como un recurso medular de una metodología visual rápida que documente el cambio cultural. El esfuerzo asume que la fotografía puede mapear e inventariar, de manera objetiva, los objetos culturales y las interacciones sociales en ambientes públicos y privados. Al mismo tiempo, considera que la cámara puede repetir la operación de registro tantas veces como sea necesario para comparar objetos y prácticas; para medir e interpretar, a través de la comparación, los procesos y las transformaciones (Collier y Collier 1986 [1967]). Si bien el hacer una etnografía visual es laborioso y requiere de tiempo, se puede acelerar su producción -según lo atestigua la experiencia en Otavalo-, en la medida de que se conozca con anterioridad otros materiales etnográficos y que se la realice de manera colaborativa. Estos son algunos de los supuestos desplegados en la observación de Vicos, una oportunidad para probar y sistematizar una metodología visual aplicada. A juicio de su hijo, este fue el esfuerzo metodológico más sistemático y sostenido de Collier Jr. para la realización de una etnografía visual y la documentación de un proyecto aplicado. Cuenta también que se pensaba repetir el procedimiento después de algunos años para observar y medir los cambios a partir de los registros iniciales tomados como línea de base. Por razones fortuitas esta iniciativa quedó trunca y nunca se repitió el registro visual (Collier 2003).

Malcolm Collier, el ya nombrado antropólogo e hijo del fotógrafo, publicó en el 2003, fragmentos de un manuscrito sobre Vicos, aún inédito, que contiene fotos de su padre, de su madre, Mary, y del peruano Abraham Guillén junto a pequeños textos explicativos de las imágenes. Los fragmentos publicados corresponden a secciones de los capítulos titulados discrepancia social, nivel agrícola, la familia, la vida social y el potencial de la vitalidad india. Este repertorio de temas reedita, en gran medida, aquellos abordados en El valle del amanecer. En este caso, el amanecer se vincula a la intervención para el mejoramiento agropecuario propiciada por las universidades -un esfuerzo controlado de persuasión por el cambio que empezará a concebirse como desarrollo-. 
La discrepancia social, sin embargo, introduce una preocupación en este nuevo momento. De manera reiterada, los estudiosos venían preguntándose qué era un indio en Latinoamérica y, de manera particular, en los Andes. Las respuestas habían sido objeto de debates en la reunión del Congreso Indigenista Interamericano realizado en Cusco y en los preparativos del censo interamericano de 1950 (Prieto 2015). Para efectos de contestar la pregunta, Collier Jr. compara campesinos indígenas y mestizos (a quienes los denomina farmers). Interroga, a través de las imágenes, si la distinción entre estos dos grupos está en su cara, en sus manos o en sus pies; o bien en su sangre, en su vestuario o en el mismo trabajo. Constata visualmente, sin embargo, que ambos tipos de campesinos viven en barrios similares, tienen una cara parecida, hablan quechua, cargan objetos pesados, visten a la misma usanza y realizan labores agropecuarias. Lo que realmente los distingue, según este autor, es que los mestizos se sienten distintos y superiores. Los mestizos, se localizan en un punto intermedio (in between) ya que comparten valores indígenas y europeos; son indios aculturados. Los indios, en cambio, se caracterizan por una posición social segregada e inferior y hablan casi exclusivamente quechua. Con ello, el autor concluye que la indigenidad es un estado mental y que el conjunto de la población andina tiene el mismo origen étnico. La discrepancia se genera, entonces, a partir de un origen étnico compartido desde el cual se transita hacia estados mentales opuestos: de un lado, aquel propio de la condición semiesclava de los indios; y, de otro lado, aquel del ciudadano libre observado en el mestizo. La comparación sirve también para demostrar que el cambio y la autonomía son posibles.

Si bien desconocemos el conjunto de la interpretación conceptual dada por el autor a esta discrepancia social, los fragmentos y fotos publicados dan cuenta de que la condición semiesclava de los indios se fragua a través del desinterés de los políticos en su condición, en el desinterés de los propios indios por la política y en su dependencia de los consejos interesados de los mestizos. La Figura 7 muestra el escorzo de un supuesto político que mira con desdén a un centro invisibilizado en la toma y que presumiblemente es la audiencia de una reunión ${ }^{18}$. Pero, pese a las condiciones de semiesclavitud y de pobreza, los indios encuentran su alegría y orgullo en el calor de la familia y del hogar. Estas relaciones se caracterizan por respeto y amabilidad y es, en estos escenarios -al igual que lo registrado en Otavalo-, donde se forja la vitalidad del pueblo indio. Y es en este espíritu de alegría, orgullo, trabajo, fiesta y música -distinto a la condición mental servil- en el cual se encuentra la energía positiva para el cambio. La servidumbre implícita en la vida de la hacienda y la condición semiesclava no han logrado, según Collier Jr., oscurecer el espíritu indio y el potencial de su vitalidad para el cambio. Y, también como en Otavalo, la niñez aparece como promesa de un futuro mejor.

$\mathrm{Al}$ igual que en Otavalo, años más tarde, Collier Jr. cuenta que las imágenes tomadas en Vicos fueron comentadas por los campesinos quienes mostraron interés en su interpretación. Allí se ensaya, una vez más, pero ahora de manera más sistemática, la idea de hacer entrevistas con fotografías. Collier Jr. prepara un conjunto de imágenes que configuran historias visuales que buscan indagar las percepciones locales sobre ellas y, así, precisar, triangular y ampliar los conocimientos de los investigadores. Varios funcionarios del proyecto Vicos fueron enviados a

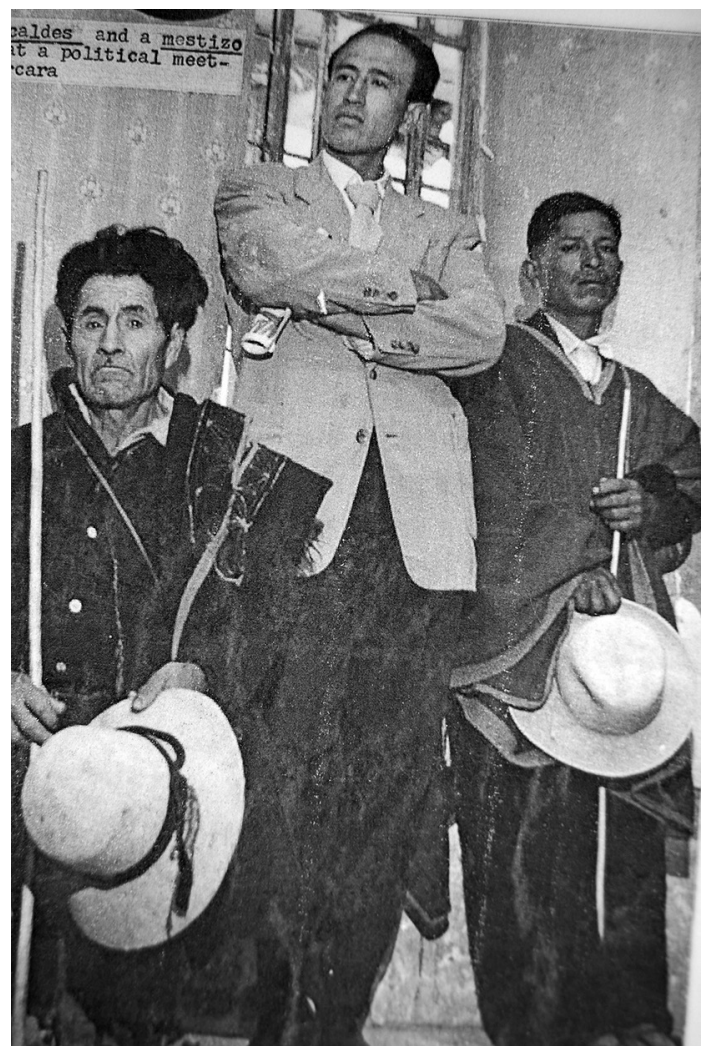

Figura 7. La indiferencia política local. Fuente: Collier 2003:177. Local political indifference. Source: Collier 2003:177. 
realizar este tipo de entrevistas. Lo que encontró, según su propio relato, es que los trabajadores de Vicos tendían a omitir los aspectos que recuerdan a la hacienda y preferían hablar de los procesos tecnológicos comprometidos con la intervención en curso. Al parecer, seleccionaban los temas sugeridos por las fotos y preguntas que a ellos les interesaba (Collier y Collier 1986 [1967]:112-113).

Con estos aprendizajes, los Andes se transforman en un laboratorio de experimentación para un nuevo subcampo de la Antropología, aquel de la visualidad. Hacia mediados de la década de 1960, John Collier Jr. y su hijo Malcolm publicaron el libro Visual Anthropology. Photography as Research Method (1986 [1967]), considerado un texto que da inicio al campo de la Antropología visual. Allí se sistematiza la experiencia de campo en una variedad de sitios para proponer a la fotografía como un método de Antropología visual. En el texto están presentes las preocupaciones por los enfoques aplicados, por la aculturación y por el método científico. Pero adquieren centralidad nuevos temas: la presencia de la cámara en el trabajo etnográfico, la noción de narrativas sociales fotográficas y la realización de estudios proyectivos con base en entrevistas fotográficas (Collier y Collier 1986 1967]) -aspectos ya tratados en El valle del amanecer y en los textos sobre Vicos-. En este nuevo texto se enriquece el uso de la metodología visual, y se explicitan los procedimientos de campo, usando las experiencias entre distintos grupos nativos de Estados Unidos, obreros en Inglaterra y nativos de Sudamérica. Los autores presentan, además, un conjunto de ideas como bases para la realización de una Antropología visual sustentada en un método científico: mapear e inventariar paisajes y establecer conexiones ecológicas, el análisis del movimiento y la quietud, los registros e inventarios de la cultura material y de las interacciones sociales y la entrevista con fotografías y su uso como proyección del modelo de vida.

\section{Hacia la Construcción de un Álbum Comunitario Móvil}

Lo que no prevén las propuestas visuales imaginadas por Collier Jr. son los efectos de la reproducción anónima de las fotografías, sus desplazamientos del corpus originalmente compuesto por el autor, ni su capacidad para cruzar entre sí renovados sentidos y afectos. Contemporáneamente, miembros de familias indígenas e instituciones de la zona de Otavalo se han apropiado de las fotografías de El valle del amanecer configurando nuevos emplazamientos e interpretaciones sobre las mismas imágenes. Con el propósito de rastrear las memorias de los individuos retratados por Collier Jr. y narrados por Aníbal Buitrón, en el 2018 se visitaron las comunidades comprometidas en el registro, llevando el libro a cuestas. De manera interesante, las personas consultadas sobre las fotos indicaron que estas les parecían familiares, pero no podían recordar sus nombres, ni lugares de residencia excepto las de don Manuel Cáceres; los individuos del libro permanecen como ancestros solo parcialmente identificados ${ }^{19}$. En esta travesía se encontró, en cambio, la exhibición de duplicados de las fotografías del libro. Las imágenes se exponen tanto en lugares públicos como en las viviendas de algunos indígenas de la zona, en un esfuerzo por construir un álbum comunitario que contiene imágenes cambiantes. Este inestable álbum combina fotos de Collier Jr., del mestizo otavaleño Humberto Castro Navarrete, de la arquitecta holandesa de la Plaza de los Ponchos de la ciudad, Tonny $Z_{\text {wollo }}{ }^{20}$, entre los que se pudieron identificar.

Las fotos de las viviendas han sido acopiadas a través de la compra de reproducciones de las imágenes del libro que se vendía en la feria de Otavalo y de regalos obtenidos de los propios fotógrafos; son objetos afectivos. Se despliegan enmarcadas y dispuestas en la pared del porche de las casas, lugar de socialización y trabajo, visible a turistas y parentela que circulen por allí. En la Figura 8 una familia observa, comenta y toca con asombro las fotos del libro, algunas de las cuales se reproducen en el acceso a su vivienda. Una de las personas entrevistadas cuenta que hace una década vio varias fotos en el mercado de Ibarra y decidió comprar tres de ellas porque les gustaron; otro recuerda haberlas comprado en la feria de Ambato. Para algunos de los entrevistados fue una sorpresa saber que las fotos provenían de un libro publicado y reimpreso en la ciudad de Otavalo; no lo conocían. En estas indagaciones, no interesó el autor de las imágenes e incluso hay confusos rumores sobre su autoría ${ }^{21}$. Fascinaba, en cambio, relatar los sentidos $\mathrm{y}$ emociones que ellas adquieren, un proceso de, podría llamarse, auto foto-elicitación.

Estas fotos se distinguen de aquellas imágenes y álbumes propiamente familiares que se guardan en la intimidad. Al decir de los consultados, a nadie le interesa recrear y recordar a los indios ni a la parentela de ahora pues se conoce como viven; se comparte con ellos en la vida cotidiana. En cambio, las fotos en 


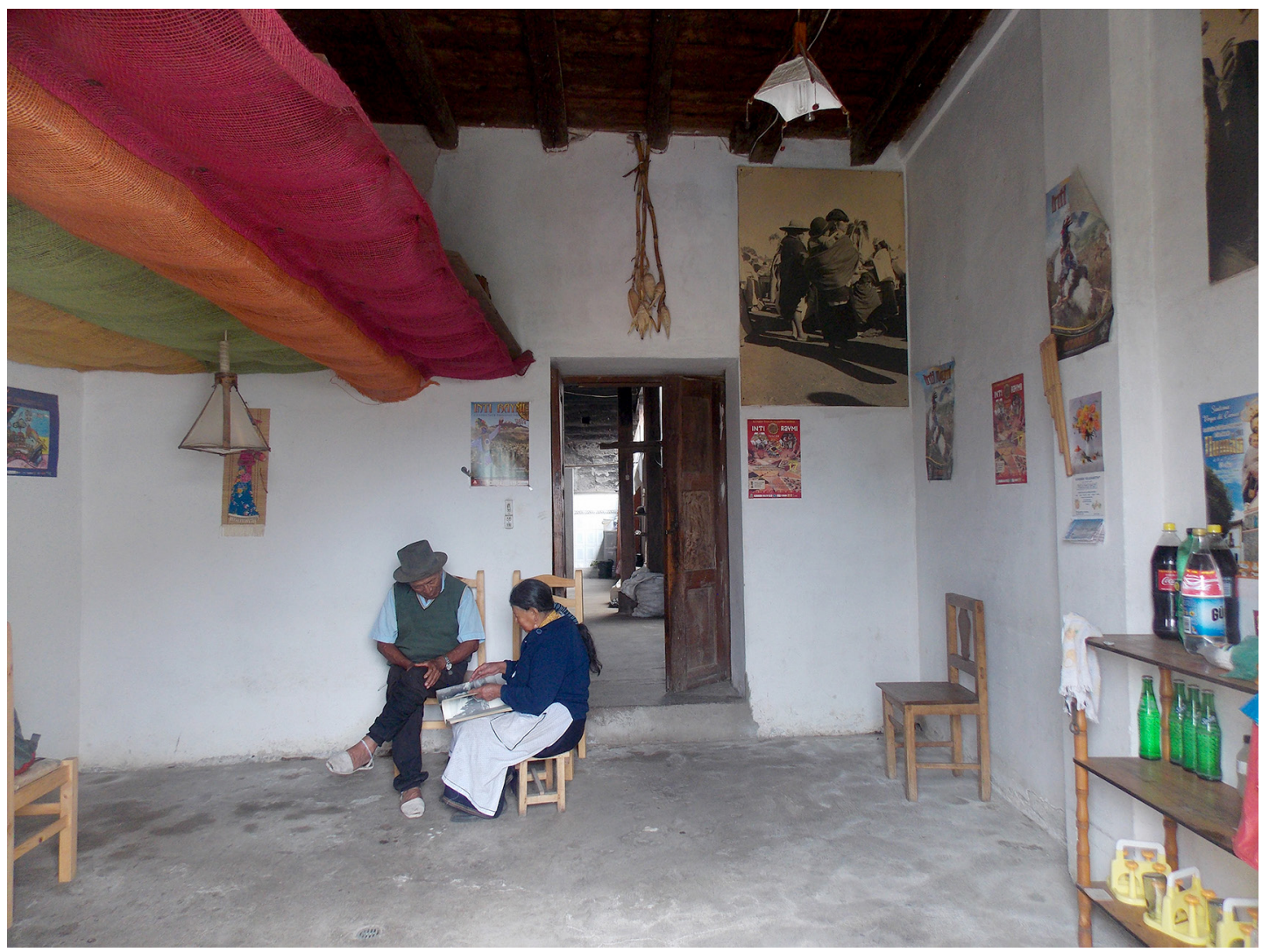

Figura 8. Configuración del álbum comunitario. Fuente: Trabajo de campo, 2018.

Arrangement of the mobile communal album. Source: Fieldwork, 2018.

blanco y negro de Collier Jr. son de una época pasada y muestran a los anónimos ancestros que abrieron caminos a comerciantes, tejedores y empresarios textiles de las generaciones contemporáneas. Se considera que tienen el valor de revelar cómo se vivía y se trabajaba en el pasado. De manera que las imágenes reúnen varios momentos en el tiempo, actúan como interlocutoras del presente y establecen una coexistencia con los ancestros (Edwards 2012:229). Estos múltiples movimientos permiten al mismo tiempo emplazar a las fotografías en la narrativa del mito otavaleño. Un entrevistado, mirando el libro, recordó que "antes vivíamos así, vivíamos así, maltratados... yo me recuerdo cómo trabajaba en la hacienda... Las fotos recuerdan esa forma de vida que tuvimos; yo tengo esas fotos para recordar que así éramos. Las fotos dicen la verdad" (Carlos Terán, entrevista 2018). Pero también rememoran a familiares fallecidos. Doña Rosa Elena de la Torre, que vendía fritada en su casa, comentó que tenía un cliente que venía a mirar la foto de su madre ya fallecida y que había sido tomada por Collier Jr. Las fotos son un recurso afectivo y de sentidos: se las mira, se las toca, se les habla con el propósito de recordar a los ancestros y las propias trayectorias de vida.

La Universidad de Otavalo, la Casa de la Juventud perteneciente al Municipio de Otavalo, la sala de exposición fotográfica de Humberto Castro y hostales privados (p.ej., Chukitos) también componen este álbum y exhiben las imágenes en la actualidad. Allí circulan turistas, estudiantes y público en general. La Casa de la Juventud tiene una exhibición permanente llamada el Otavalo de ayer. Con este propósito adquirieron fotos de Humberto Castro, pero se desconoce cómo obtuvieron las fotos de Collier Jr. El estudiantado de la zona suele visitar esta exhibición para observar los cambios de la ciudad y sus alrededores, así como los cambios de la propia población indígena.

En la Universidad de Otavalo se repite este interés por acopiar fotos del pasado de los indígenas -considerados de manera paternalista como "nuestros indígenas"-. Este pasado se lo observa como marcado 
por la pobreza y necesidades, pero también por la "cultura" en referencia a las fiestas y ritos, los vestidos, el comercio, la agricultura y la artesanía. Las imágenes permiten reiterar una narrativa del mito otavaleño pues, a través de ellas, se "hace ver que este pueblo ha sido muy emprendedor, muy trabajador... un pueblo digno, un pueblo culto, un pueblo que a lo largo de los años... todavía se conserva, eso es digno de aplauso y reconocimiento" (Patricio Guerra, entrevista 2018). El álbum comunitario es, entonces, como un pastiche de imágenes de diversas proveniencias acompañadas de narrativas contemporáneas de la vida del pueblo nativo Otavalo, que rememoran un pasado de maltratos, pobreza y riqueza "cultual". Pero, al mismo tiempo, estas distintas narrativas están orientadas a mostrar el esfuerzo realizado por los indígenas para lograr su actual bienestar, experiencias que deben trasmitirse a las nuevas generaciones, pero también a turistas y conciudadanos. Estas nuevas narrativas fotográficas son medios para valorar, empatizar y normalizar los logros de la elite nativa (Colloredo-Mansfeld 1999), pero ocultando las persistentes desigualdades entre los propios otavaleños.

\section{Conclusiones}

La fotografía como tecnología del conocer adquiere nuevos sentidos hacia los años de 1940, en tanto se constituye en Estados Unidos en uno de los objetos de una emergente Antropología visual y en tanto busca registrar el cambio social. Durante la guerra y la posguerra, la antropología norteamericana se expandió hacia una geografía global y hacia nuevos intersticios de encuentros entre disciplinas, al tiempo que se conjuga con una política global prodemocracia, uno de los ejes de la disputa de la Guerra Fría sobre los contenidos de la modernidad. En este marco, la Antropología norteamericana se teje con nuevas necesidades de conocer e interpretar de manera universal el cambio social vivido por obreros y poblaciones nativas del mundo, un desafío sistematizado en centros de cálculo descentrados como el III, la OIT y la UNESCO. La visualidad, tratada en la época como una inspección positivista de la realidad, facilita registrar y estabilizar observaciones y medidas de los cambios. Al mismo tiempo, sin embargo, se reconoció a la fotografía como un recurso artístico y sujeto a narrativas e interpretaciones. Los Andes se articulan a la producción de este emergente campo visual, bajo un enfoque en torno al mejoramiento de las vidas de lo que se llamaba población indígena, un segmento segregado de la vida política y económica de las naciones. El registro de procesos de aculturación dirigidos a la conformación de sujetos aptos para la democracia, así como la experimentación conceptual, son contribuciones de los Andes a la fundación de la Antropología visual aplicada. En esta emergente Antropología visual andina opera una constelación de conceptos con múltiples sentidos (Kozelleck 2004).

Los procesos de aculturación de los pueblos indígenas en los Andes ocurrieron en contextos en los cuales la población indígena era mayoritaria. Las intervenciones entre poblaciones nativas en Estados Unidos y otros lugares (p.ej., Nueva Zelanda), producidas y reforzadas en diversos centros de conocimiento, originaron la sistematización de experiencias basadas en la consideración de que la población originaria vivía en reservas o eran minorías. El aporte de los Andes $^{22}$ a esos distintos centros es rica, en contraste, en dos sentidos: la mayoría demográfica de la población nativa y la memoria de un pasado glorioso -como el del Incanato-. Estas aproximaciones buscaban mostrar que la población originaria puede retomar la senda del progreso a través de sus propias iniciativas de mercado o a través de una persuasión externa controlada.

Efectivamente, los Andes despliegan la agenda proindígena y prodemocracia de la Antropología de la posguerra: una democracia basada en el mercado, en el caso de Otavalo, y una democracia basada en intervenciones de desarrollo, en el caso de Vicos -ambas pensadas para reproducirse en diferentes lugares del mundo-. Ambas rutas buscan reconocer y rescatar un ethos indígena congruente con la democracia. A diferencia de otras experiencias latinoamericanas y de otros nodos de conocimiento, la antropología en los Andes no buscó borrar la indigenidad, sino colocarla como el motor del cambio social, bajo el concepto de energía para el cambio; contribuyó a la elaboración de teorías de aculturación que fomentaban la indigenidad antes que su evaporación. Las ideas de contexto, de movimiento y de energía para el cambio fueron potenciadas mediante una noción de cambio social tridimensional: las estructuras económicas y políticas, su reproducción y movimiento y los agentes del cambio. Al poner atención en los agentes del cambio y sus energías para impulsarlo, se propuso una indigenidad de la convivencia democrática y de los estados de ánimo.

Pero los Andes no solo participó con nuevas aristas sobre la teoría de la aculturación, sino que fue, también, un laboratorio para el desarrollo de 
las teorías visuales: la entrevista con fotografía (que posteriormente se transforma en foto-elicitación) y las narrativas fotográficas son dos elaboraciones probadas en diversos lugares. La experiencia en Otavalo mostró las condiciones para formular, en el hacer, la narrativa fotográfica. Los fotografiados hablaron poco, pero sus imágenes permiten una poderosa narrativa del cambio social, una acción que se reitera, contemporáneamente, con el álbum comunitario móvil. En cambio, Vicos proporcionó las condiciones para la formalización de las entrevistas con fotografías, en la cual el investigador tiene un papel central al facilitar el proceso de conocimiento y simular ser el agente externo promotor del cambio. En ambos casos, la fotografía ofreció el montaje y puso en escena las teorías visuales propuestas por John Collier Jr. desde su experimentación en los Andes. Pero lo inesperado de este montaje y perfomance de las fotografías es que la población actual de Otavalo, indígena y mestiza, cuestiona la autoría de Collier Jr., se ha apropiado de sus imágenes y ha compuesto una suerte de álbum comunitario móvil que transmite nuevas interpretaciones del pasado de la población otavaleña y de sus ancestros con quienes mantienen vínculos afectivos. La capacidad de reproducción de la fotografía permite su desplazamiento y sus nuevos emplazamientos, tejidos con el afecto hacia la imagen misma y hacia los ancestros, erosionando su sentido primordial y exclusivo como documento del saber científico.

Agradecimientos: José Manuel Perugachi merece un agradecimiento especial por su apoyo en el trabajo de campo realizado en las comunidades fotografiadas, en la década de 1940 en la zona de Otavalo, por John Collier Jr. y Aníbal Buitrón en su libro El valle del amanecer; asimismo, agradezco los comentarios a diversas versiones de este escrito que recibí de mis colegas de FLACSO Ecuador, del proyecto L.A. Global de ILAS de la Universidad de Londres y del Instituto de Antropología de la Pontificia Universidad Católica de Chile. Finalmente, agradezco los comentarios recibidos de revisores anónimos, que contribuyeron a mejorar el manuscrito.

\section{Referencias Citadas}

Bee, R.L. 1974. Patterns and Processes. Macmillan Publishing Co., Nueva York.

Biella, P. 2002. The Legacy of John Collier, Jr. Visual Anthropology Review 17 (2):1-11.

Blanchette, T. 2010. La antropología aplicada y la administración indígena en los Estados Unidos: 1934-1945. Desacatos 33:33-52.

Bolton, R., T. Greaves y F. Zapata (eds.) 2010. 50 años de Antropología Aplicada en el Perú: Vicos y Otras Experiencias. Instituto de Estudios Peruanos, Lima.

Cánepa, G. e I. Kummels (eds.) 2016. Photography in Latin America: Images and Identities Across Time and Space. Transcript Verlag, Bielefeld.

Collier, J. Jr. 1957. An Experiment in Applied Anthropology (with M.E.T. Collier). Scientific American 59:37-49.

Collier, J. Jr. 1987. Visual anthropology's contribution to the field of Anthropology. Visual Anthropology 1 (1):37-46.

Collier, J. Jr. 1988. Visual anthropology and the future of ethnographic film. En Anthropological Filmmaking. Anthropological Perspectives on the Production of Film and Video for General Public, editado por J.R. Rollwagen, pp. 73-96. Hardwood Academic Publisher, Amsterdam.

Collier, J. Jr. 1995. Photography and visual anthropology. En Principles of Visual Anthropology, editado por P. Hockings, pp. 235-254. Mouton de Gruyter, Nueva York.

Collier, J. Jr. y A. Buitrón 1971 [1949]. El Valle del Amanecer (The Awakening Valley). Instituto Otavaleño de Antropología, Otavalo.
Collier Jr., J. y M. Collier 1986 [1967]. Visual Anthropology: Photography as a Research Method. University of New Mexico Press, Albuquerque.

Collier, M. 2003. The Vicos photographs of John Collier Jr. and Mary E.T. Collier. Visual Anthropology 16 (2-3):159-206.

Colloredo-Mansfeld, R.J. 1999. The Native Leisure Class: Consumption and Cultural Creativity in the Andes. The University of Chicago Press, Chicago.

Degregori, C.I. y P. Sandoval 2008. Saberes Periféricos: Ensayos Sobre la Antropología en América Latina. Instituto de Estudios Peruanos e Instituto Francés de Estudios Andinos, Lima.

Didi-Huberman, G. 2015. Remontajes del Tiempo Padecido. El Ojo de la Historia 2. Biblos, Buenos Aires.

Doughty, P. 2010. Trayectorias antropológicas: Vicos y el Callejón de Huaylas, 1948 al 2006. En 50 Años de Antropología Aplicada en el Perú: Vicos y Otras Experiencias, editado por R. Bolton, T. Greaves y F. Zapata, pp. 83-122. Instituto de Estudios Peruanos, Lima.

Dubois, P. 1994 [1986]. El Acto Fotográfico. Paidós, Barcelona.

Edwards, E. 1992. Introduction. En Anthropology and Photography, 1860-1920, editado por E. Edwards, pp. 3-17. Yale University Press y The Royal Anthropological Institute, New Haven y Londres.

Edwards, E. 2012. Objects of affect: Photography beyond the image. Annual Review of Anthropology 41:221-234.

Field, T. Jr. 2016 [2014]. Minas, Balas y Gringos. Bolivia y la Alianza para el Progreso en la Era de Kennedy. Centro de Investigaciones Sociales, La Paz. 
Gilbert, J.M., C.C. Le Grand y R.D. Salvatore 1998. Close Encounters of Empire: Writing the Cultural History of US and Latin American Relations. Duke University Press, Durham.

Gupta, A. y J. Ferguson 1997. Culture, Power and Place: Explorations in Critical Anthropology. Duke University Press, Durham.

Kehoe, A.B. y P.L. Doughty (eds.) 2012. Expanding American Anthropology, 1945-1980. A Generation Reflects. The University of Arkansas Press, Tuscaloosa

Koselleck, R. 2004. Historia de los conceptos y conceptos de historia. Ayer 53 (1):27-45.

Levine, R.M. 1989. Images of History: Nineteenth and Early Twentieth Century Latin American Photographs as Documents. Duke University Press, Durham.

Malkki, L. 1992. National Geographic: The rooting of people and the territorialization of national identity among scholars and refugees. Cultural Anthropology 7 (1):24-44.

Métraux, A. 1962. Incas of Today. Correo de la UNESCO 15:15-21.

Métraux, A. 1969. The History of the Incas. Pantheon Books, Nueva York.

Parsons, E.C. 1945. Peguche, Canton of Otavalo, Province of Imbabura, Ecuador. A Study of Andean Indians. University of Chicago Press, Chicago.

Pink, S. (ed.) 2007. Visual Interventions. Applied Visual Anthropology. Berghahn Books, Nueva York y Oxford.

Poole, D. (ed.) 2008. A Companion to Latin American Anthropology. Blackwell Publishing, Oxford.

Poole, D. 2000 [1997]. Visión, Raza y Modernidad. Una Economía Visual del Mundo Andino de Imágenes. Sur Casa de Estudios del Socialismo, Lima.

Poole, D. y G. Zamorano 2012. De Frente al Perfil: Retratos Raciales de Frederick Starr. El Colegio de Michoacán, Zamora.

Prestarino, J. 2018. Álbumes fotográficos producidos por André Roosevelt en Ecuador: un análisis de su producción y accesibilidad. Revista Photo \& Documento 5. http://gpaf.info/ photoarch/index.php?journal=phd\&page $=$ article $\&$ op $=$ view $\&$ path $\% 5 \mathrm{~B} \% 5 \mathrm{D}=152$.

Prieto, M. 2010. Indigenismo: La red interamericana. En Ecuador y México: Vínculo Histórico e Intercultural, compilado por J.F. Regalado, pp. 251-264. Museo de la Ciudad, Quito.

Prieto, M. 2015. El estado ecuatoriano a mediados del s. XX: El censo, la población y la familia indígena. European Review of Latin American and Caribbean Studies 99:29-46.
Prieto, M. 2016. Estado y Colonialidad. Mujeres y Familias Quichuas de la Sierra del Ecuador, 1925-1975. FLACSO, Quito.

Prieto, M. (compil.) 2017. El Programa Indigenista Andino, 19511973. Las Mujeres en los Ensambles Estatales del Desarrollo. FLACSO e Instituto de Estudios Peruanos, Quito y Lima.

Prieto, M., L.A. Briceño y A. Fonseca 2021. Hitos en los estudios de la Etnohistoria: una mirada desde los Andes. En Etnohistoria: Miradas Renovadas y Conectadas, coordinado por M. Prieto, L.A. Briceño y A. Fonseca. FLACSO, Quito. En prensa.

Prieto, M. y C. Páez 2017. El Programa Indigenista Andino. Integración-desarrollo, estado y mujeres indígenas. En El Programa Indigenista Andino, 1951-1973. Las en los ensambles estatales del desarrollo, coordinado por M. Prieto, pp. 5-49. FLACSO e Instituto de Estudios Peruanos, Quito y Lima.

Purcell, F. y M. Casals 2015. Espacios en disputas: el Cuerpo de Paz y las universidades sudamericanas durante la Guerra Fría de la década de 1960. Historia Unisinos 19 (1):1-11.

Reyero, A. 2012. Imagen, objeto y arte: la fotografía de Guido Boggiani. Íconos 42:33-49.

Rosenblatt, K.A. 2018. The Science and Politics of Race in Mexico and the United States, 1910-1950. University of North Carolina Press, Chapel Hill.

Scherer, J.C. 1992. The Photographie Document: Photographs as Primary Data in Anthropological Enquiry. En Anthropology and Photography, 1860-1920, editado por E. Edwards, pp. 32-41. Yale University Press y The Royal Anthropological Institute, New Haven y Londres.

The Social Science Research Council Summer Seminar on Acculturation, 1953. 1954. Acculturation: An exploratory formulation. American Anthropologist 56:973-1000.

Troya, M.F. 2012. Un segundo encuentro: la fotografía etnográfica dentro y fuera del archivo. Íconos 42:17-31.

Weyer, E. 1950. Book Review. The Awakening Valley. John Collier Jr. and Aníbal Buitrón (University of Chicago Press, 1949). American Anthropologist 52 (2):249-250.

Windmeijer, J. 2016 [2001]. El Valle Amanecido. Un Estudio de los Indígenas Ejemplares de Otavalo, Ecuador. Abya-Yala, Quito.

Wright, T. 1992. Photography: Theories of Realism and Convention. En Anthropology and Photography, 1860-1920, editado por E. Edwards, pp. 18-31. Yale University Press y The Royal Anthropological Institute, New Haven y Londres.

Zamorano, G. 2009. 'Intervenir en la realidad': usos políticos del video indígena en Bolivia. Revista Colombiana de Antropología 45 (2):259-255.

\section{Notas}

1 La experiencia en estos diferentes escenarios está registrada en el clásico texto fundacional de este subcampo, escrito por John Collier Jr. y su hijo Malcolm Collier (Collier y Collier 1986 [1967]). John Collier Jr. es miembro de una reconocida familia de antropólogos en la cual destaca su padre, John Collier quien, como administrador de la Oficina de Asuntos
Indios de Estados Unidos y como promotor del Instituto Indigenista Interamericano, armó importantes vínculos con antropólogos mexicanos y de la región (Blanchette 2010; Rosenblatt 2018).

2 Esta pieza se reimprimió en 1971 por parte del Instituto Otavaleño de Antropología y es la versión utilizada en este 
análisis. La publicación inicial fue comentada por Edward Weyer (1950), del Museo Americano de Historia Natural de Nueva York, quien la propone como un registro visual del "milagro social" de los indios Otavalo del Ecuador, basado en la industria textil la cual les permitió adquirir tierras.

3 Margaret Mead en una conferencia persuade al público de que la Antropología es la ciencia que facilita la promoción de la democracia global (citado en Kehoe y Doughty 2012:11). Junto a este impulso a la democracia desde ámbitos académicos, varios antropólogos trabajaron en el ejército de Estados Unidos en funciones de inteligencia; fomentaban la cooperación internacional, entre otras acciones. Existe una amplia literatura sobre los efectos del New Deal y de la Guerra Fría en la vida cotidiana y en la institucionalidad política de Latinoamérica. Algunos estudios muestran los efectos contradictorios de las políticas norteamericanas en la región. Por ejemplo, en Bolivia se destaca el rol de la Alianza para el Progreso en la instalación de formas autoritarias de gobierno en ese país (Field 2016 [2014]); asimismo, estudios sobre el Cuerpo de Paz en Sudamérica muestran cómo las universidades se transformaron en escenarios de disputas ideológicas en torno a las maneras de concebir la modernidad global (Purcell y Casals 2015).

4 La idea de aculturación, como adaptación a nuevos entornos culturales, es una propuesta de los discípulos de Franz Boas y Alfred Kroeber; los primeros estudios con este enfoque se publicaron en la década de 1930. Mientras tanto, la Antropología británica entiende el cambio cultural en el marco de lo que se llama "contacto cultural" como un producto forzado del colonialismo (Bee 1974:94), noción que también es posible rastrearla entre los estudiosos norteamericanos del cambio cultural. El seminario auspiciado por SSRC sobre el tema de la aculturación en 1953 propone la siguiente definición: "Acculturation may be defined as culture change that is initiated by the conjunction of two or more autonomous cultural systems" (Acculturation 1954:974). Allí se discutieron aspectos tales como los factores de la aculturación, el contacto, los resultados de la aculturación, las relaciones interculturales, la personalidad y la aculturación, el uso de la arqueología, la lingüística y las historias de ancianos en la exploración de la aculturación; se hizo, también, un llamado a una reflexión metodológica el tema.

5 Karin Rosenblatt (2018) estudia el modelo de la aculturación en México como uno de carácter aplicado y universal y lo articula a los prevalentes conceptos evolucionistas de los intelectuales locales y al contexto socialista del cardenismo. A juicio de esta autora, esta antropología en México buscaba construir la nación mexicana mientras que en Estados Unidos se pensaba en la administración de la emergente condición imperial de ese país.

6 Existe una amplia literatura que reflexiona sobre la historia de los estudios andinos la cual discute el esencialismo temporal y cultural, el nacionalismo y la globalización (Poole 2008; Prieto et al. 2021) así como aspectos de su colonialidad (Degregori y Sandoval 2008).

7 Es interesante constatar que en Ecuador la enseñanza sistemática de la antropología solo se establece en la década de 1970. Previo a ello, se identifica con el sistema de Naciones Unidas y su Programa Indigenista Andino que creó incentivos para la formación en el exterior, especialmente
México. El requerimiento de antropólogos en la década de 1950 se suple a través de otras profesiones como las de profesores y trabajadores sociales.

8 André Roosevelt publica, de manera artesanal, Andean Paradise (1939), Quito Chachis (1939) y Haven (1940). Recién se está investigando algunos fragmentos de la convergencia de esta serie de fotógrafos en Quito y de sus vínculos con la antropología, como lo atestigua el trabajo de Julieta Prestarino (2018) y la exhibición Solo a través del otro puedo saber quién soy. Memorias fotográficas de la inmigración europea al Ecuador (1930-1970) (junio-agosto 2018. Curaduría de Paulina León. Museo de la Ciudad, Quito). Allí se incluyen las obras de Rolf Blomberg, Olga Fisch, Karl Goldschmidt, Gottfried Hirtz, Isidor Kaplan, Hans y Gi Neustätter, Erwin Patzelt y Arthur Weilbauer.

9 El hijo de John Collier Jr. cuenta que su padre inició su trabajo en los Andes con el auspicio de Roy E. Stryker y de la Standard Oil Co. de Nueva Jersey, de la cual se independiza tempranamente (Collier 2003). Cuenta también que en Perú participó en varios eventos en donde conoció a Aníbal Buitrón, Alan Holmberg, Junius Bird y Abraham Guillén, entre otros estudiosos de los Andes.

10 Esta noción de comunidad de antropólogos debe entenderse como una convergencia flexible, cambiante y controversial; sospechas y disputas se exhiben constantemente.

11 No debe olvidarse que, en el discurso de inauguración de la reunión de Pátzcuaro, el entonces presidente mexicano advirtió sobre los riesgos del comunismo entre las poblaciones indígenas y la necesidad de prevenir su expansión (Prieto 2010).

12 En el estudio sobre el Programa Indigenista Andino auspiciado por la OIT y las agencias de Naciones Unidas, se constata que la documentación está dispersa en varios centros: las sedes de Lima y Ginebra de la OIT, la sede parisina de la UNESCO, las publicaciones del III, centros estatales de las naciones andinas y archivos privados; son centros descentrados de cálculo.

13 Jeroen Windmeijer (2016 [2001]) ha analizado recientemente esta mirada positiva de los indios de Otavalo evidenciando una agenda interesada de funcionarios estatales, agentes turísticos, grupos indígenas, entre otros, quienes han creado el mito de indio exitoso, dejando de lado una serie de exclusiones y desigualdades.

14 Es interesante constatar que la familia de Aníbal Buitrón es parte de esta burocracia estatal. Es presumible que el comisario nacional que aparece en la foto que reproducimos (Figura 2) sea el padre del antropólogo.

15 Los vínculos entre lugares y las poblaciones nativas han sido un poderoso mecanismo de los estudios etnográficos orientada a la adscripción de estos grupos a lugares apropiados (Gupta y Ferguson 1997; Malkki 1992).

16 En la época de que se produjeron estas fotos, estaba muy difundido en la zona de Otavalo el temor a las cámaras y a la fotografía por sus supuestas capacidades de apoderarse del alma de las personas, pero también se trataba de la disuadir los contactos con extraños. Sin embargo, rápidamente con la expansión del turismo y del comercio este temor desapareció y hoy en día, cámaras y artefactos digitales son parte de la cotidianidad de las comunidades y ciudades (trabajo de campo 2018). 
17 Carlos Contarón, quien conoció a Manuel Cáceres, indica hoy día que en las fotos Manuel está posando, pero reconoce al mismo tiempo que esa era la forma de trabajar (entrevista 2018).

18 Ambos comportamientos fueron usados por las autoridades de las naciones andinas (excepto Bolivia) para privar a los analfabetos de los derechos al voto debido a su supuesta falta de autonomía.

19 Carlos Conterón y Rosa Elena de la Torre (entrevista 2018) sostienen haber conocido a las personas retratadas mientras trabajaban en su puesto de venta en el mercado, vecino de Manuel Cáceres. Una importante proporción de las fotos corresponde a su familia y a la comunidad de Ilumán, incluyendo las yachag (trabajo de campo 2018). A Carlos
Terán y Lusmila Pineda (entrevista 2018), por su parte, las personas les parecen familiares por sus vestidos.

20 Tonny Zwollo en el 1971 reprodujo una de las fotos de Collier Jr. con la misma persona; copia de esta réplica reposa en la vivienda de Carlos Terán (trabajo de campo 2018).

21 Varias personas indicaron que el verdadero autor es un fotógrafo de Otavalo y que Collier Jr. le habría plagiado.

22 Esta característica la comparten Mesoamérica y los Andes. Sin embargo, las políticas de la indigenidad son diferentes en estas localidades. Mientras Mesoamérica abogaba por un mestizaje cósmico, en los Andes se rescataron aspectos cooperativos de la indigenidad y el mantenimiento de la condición nativa. 